The research program of the Center for Economic Studies (CES) produces a wide range of theoretical and empirical economic analyses that serve to improve the statistical programs of the U.S. Bureau of the Census. Many of these analyses take the form of CES research papers. The papers are intended to make the results of CES research available to economists and other interested parties in order to encourage discussion and obtain suggestions for revision before publication. The papers are unofficial and have not undergone the review accorded official Census Bureau publications. The opinions and conclusions expressed in the papers are those of the authors and do not necessarily represent those of the U.S. Bureau of the Census. Republication in whole or part must be cleared with the authors.

\title{
A WARM EMBRACE OR THE COLD SHOULDER: WAGE AND EMPLOYMENT OUTCOMES IN ETHNIC ENCLAVES
}

\author{
by \\ Roberto Pedace * \\ Claremont Graduate University \\ and \\ Stephanie Rohn * \\ University of Southern California
}

CES 08-09 April, 2008

All papers are screened to ensure that they do not disclose confidential information. Persons who wish to obtain a copy of the paper, submit comments about the paper, or obtain general information about the series should contact sang V. Nguyen, Editor, Discussion Papers, Center for Economic Studies, Bureau of the Census, 4600 Silver Hill Road, 2K132F, Washington, DC 20233, (301-763-1882) or INTERNET address sang.v.nguyen@censu.s.gov. 


\begin{abstract}
This paper examines how immigrant enclaves influence labor market outcomes. We examine the effect of ethnic concentration on both immigrant earnings and employment in high immigration states using the non-public use, 1-in-6 sample of the 2000 U.S. Census. Although we find that there is some variability in the estimated enclave effects, they exhibit an overall negative impact. Male and female immigrants from several ethnic groups tend to earn lower wages when residing in areas with larger ethnic concentrations. Similarly, for employment, most of the statistically significant effects are negative, although much smaller than the enclave impacts on earnings.
\end{abstract}

JEL Classification: J61, J15, R23

Keywords: Immigrant labor outcomes; Ethnic enclaves

* The paper benefitted from the suggestions of Cynthia Bansak, Stephen Conroy, Catalina Amuedo-Dorantes, and Mary Lopez. The authors also thank Rebecca Acosta, Kevin McKinney, and Arnold Reznek for their help in acquiring access to the data. Financial support provided by the Haynes Foundation and the University of Redlands was greatly appreciated. The data used are confidential under Title 13, United States Code. Access was obtained through the Center for Economic Studies (CES) at the U.S. Census Bureau. Researchers can access the data files with a CES approved proposal (see http://www.ces.census.gov). The research in this paper was conducted while the authors were Special Sworn Status researchers of the U.S. Census Bureau at the California Census Research Data Center, Los Angeles. Research results and conclusions expressed are those of the authors and do not necessarily reflect the views of the Census Bureau. This paper has been screened to insure that no confidential data are revealed. 


\section{Introduction}

The enclave economy hypothesis claims that social ties created by similarities in culture and language generate networks that create optimal employment matches for immigrants and protect them from difficult adjustment periods. The idea is that existing businesses owned by immigrants, or workplaces that employ a large fraction of foreign-born workers, can provide advantageous labor market opportunities. Rather than encounter unemployment or low wage jobs at the bottom of the occupational hierarchy, immigrants can use networks in ethnic enclaves to gain employment at higher wages. While this is plausible, the hypothesis ignores the possibility that higher concentrations of immigrants may increase competition for jobs within the enclave, resulting in lower wages and job displacement. In addition, a low-wage, highunemployment outcome is possible if the enclave functions primarily as a form of secondary labor market for the lowest-skilled immigrants.

The purpose of this paper is to examine how ethnic enclaves influence the labor market outcomes of foreign-born workers. Previous studies investigating this issue have been limited in scope, relying on public-use datasets or focusing on few ethnic groups. The restricted household location information in public-use data is not ideal for studying enclaves because immigrant networks could function differently over large and small geographic areas. Another factor that, in some cases, has been overlooked in previous studies using large cross-sections of the population is the distinction between residence and work location. There are two possibilities that make this distinction important in obtaining unbiased estimates of the enclave effect. First, if the enclave economy is a high-wage network, low-skill immigrants who choose to reside in the enclave for social benefits may seek work outside of the enclave. If so, failing to control for work location will result in estimated enclave effects that are biased downward. On the other 
hand, if the enclave is a low-wage network, high-skill immigrants are likely to seek work outside of the enclave. If that is the case, the enclave effect will be biased upward as the higher wages obtained by those commuting immigrant workers are attributed to their household rather than work location.

This study addresses these issues with the following improvements. First, we use one of the largest household/individual databases available from the U.S. Census Bureau (not publicuse), with more than 1 million sample observations from California, Florida, Illinois, New Jersey, New York, and Texas. Second, the large sample size allows us to examine enclave effects for many ethnic groups. Unlike most other studies that have been limited to a few (or less) ethnic groups, we define 9: Mexican, Central American, South American, Puerto Rican, Cuban, West Asian, East Asian, European, and "other” foreign-born. Finally, within this crosssection of states, we are able to exploit immigrant concentration in many smaller geographic areas. Other studies using public-use data have had to rely on state or metropolitan area concentrations to proxy for the size and influence of an enclave. Our ability to identify smaller areas allows us to capture unique ethnic enclaves that may co-exist within the larger urban metropolis and simultaneously identify those whose residence and work locations differ.

In order to estimate the enclave effect, we specify a series of individual-level wage and employment equations that control for years since migration, English language abilities, and other observable human capital and demographic characteristics. A measure that captures the proportion of the county, county subdivision, or census tract that is populated by a particular ethnic group is introduced into the model and enclave effects are estimated for each ethnic group. The results suggest that the costs (i.e., increased competition for jobs) associated with living in an enclave generally outweigh possible labor market benefits. For both males and females, in 
most ethnic groups, larger enclaves are associated with lower wages. The employment effects tend to be insignificant or small in magnitude. On the whole, the results do not support the enclave economy hypothesis and imply that most immigrants would experience more favorable labor market outcomes by locating in areas with less concentration of foreign-born workers with the same ethnic background.

\section{Existing Literature}

Early empirical work by Wilson and Portes (1980) finds that immigrants in enclaves received returns to human capital characteristics similar to those in primary sector employment and significantly higher than those employed in secondary sector jobs. They conclude that the enclave provides better opportunities than the open labor market for immigrant workers. Problems with this study, however, include a small sample size (less than 600 individuals), only one ethnic group (Cuban refugees), a narrow definition of participation in an enclave (employment at a Cuban-owned firm), and a single labor market (Miami). ${ }^{1}$ It is not possible to identify whether these outcomes are truly the result of positive enclave effects or due to characteristics that are unique to Cuban refugees, Cuban-owned firms, and/or the Miami labor market. Some work in the economic assimilation literature suggests that Cubans obtain higher returns to human capital and attain wage convergence at a faster rate than other Hispanic groups (Borjas 1982). One explanation that has been offered for this is the higher opportunity costs of failure faced by political immigrants who may not have an option of returning to their country of origin (Borjas 1982; James, Romine, and Terry 2002). Consequently, the positive enclave effects may not hold with a more diverse group of immigrants.

\footnotetext{
${ }^{1}$ Portes and Jensen (1989), using a larger sample from the 1980 public-use Census microdata, also find that the enclave is associated with positive outcomes for male and female Cubans in Miami.
} 
The definition of an ethnic enclave has been malleable throughout the literature; it has been defined by location of residence, location of job, and a cluster of immigrant firms. Zhou and Logan (1989) estimate earnings equations for Chinese immigrants in New York City in the early 1980s using each definition and find that, overall, there are positive returns to earnings for college education and mixed returns to English-speaking abilities and labor force experience. Mar (1991) also examines the labor market outcomes of Chinese immigrants, but focuses on the San Francisco labor market rather than New York. Utilizing a sample of individuals who arrived between 1965 and 1975, his findings show that Chinese immigrants who worked in Chineseowned firms experience lower earnings and fewer promotional opportunities. Using measures of local ethnic concentration, which have become more common in the literature, Sanders and Nee (1987) find that Chinese wage and salary earners in Los Angeles are negatively affected by enclaves. Also, Asian immigrants in Los Angeles tend to search for higher paying jobs outside of the enclave as time and work experience increase, and earn higher wages as a result (Nee, Sanders, and Sernau 1994). ${ }^{2}$ Discrepancies in studies of the same ethnic group suggest that differences in local labor market characteristics cannot be ignored.

Gonzalez (1998) uses a large sample of Mexican immigrants residing in California and Texas metro areas. Earnings equation estimates that control for individual human capital and several local area characteristics imply that Mexican immigrants experience significant earnings losses as a result of residing in areas with larger ethnic concentrations. Despite the presence of controls for labor market characteristics, it is not possible to determine if these effects are unique to Mexican workers or if ethnic concentration is associated with the unobserved productivity characteristics of this immigrant group. Chiswick and Miller (2005) find negative earnings effects for both Mexican and non-Mexican immigrants in a larger sample of workers across the

2 This finding also appears to hold in recent work focusing on Cubans in the Miami-area labor market (Davis 2004). 
U.S. Nevertheless, their use of state-level measures of ethnic concentration cast some doubt on the ability of the study to capture enclave effects and make it impossible to disentangle the impacts of enclaves from local labor market conditions.

As in the studies by Gonzalez (1998) and Chiswick and Miller (2005), Chowdhury and Pedace (2007) also utilize the public-use sample of the 1990 Census. This data is used to obtain measures of immigrant concentration in metropolitan areas within the state of California. A difference-in-difference (D-in-D) estimation technique allows them to simultaneously control for ethnicity and metro area fixed effects. Although they initially find negative enclave effects for South American and Mexican workers, all of the enclave effects become insignificant in the Din-D estimates. It continues to remain questionable, however, whether metro areas are an appropriate level of aggregation for identifying enclaves. In sum, if work location is ignored, only broad ethnic categories are identified, and concentration measures are calculated over large geographic areas, then earnings effects may be disguised and the estimated impact of enclaves will be biased.

\section{Theoretical and Empirical Framework}

Our theoretical structure is based on the work of Edin, Fredriksson, and Aslund (2003). In this model, immigrants' location decisions are assumed to be based on their potential income and other amenities available in various locations. Thus, the benefits derived from residing in an ethnic enclave are

$$
U_{i c}=f_{i}\left(e_{c}\right)+y_{i c}
$$


where the $i$ and $c$ subscripts represent individual and location (county, county subdivision, or census tract), respectively, $e$ measures ethnic concentration, and $y$ is a labor market outcome measure. Benefits derived from $f_{i}\left(e_{c}\right)$ might include, for example, opportunities for immigrants to continue speaking in their native language and participation in other cultural activities tied to the immigrants' countries of origin. Immigrants are likely to find these activities to be an important part of their life and will resist moving away from enclaves for long periods of time (Funkhouser 2000).

The labor market outcome, $y$, is assumed to be a function of individual human capital attributes and specific immigrant assimilation characteristics (Chiswick 1978; Borjas 1995). The size of the ethnic enclave is also allowed to exert some influence. Ethnic networks may affect immigrants' income by improving the transfer of local labor market information and creating more efficient job matches or, conversely, higher ethnic concentrations could adversely impact wage and employment opportunities by increasing the intensity of competition in the local labor market. $^{3}$ The resulting baseline model for labor market outcomes can be represented by

$$
y_{i c}=\alpha+\mathbf{x}_{i c} \boldsymbol{\beta}+\theta s_{i c}+\varphi s_{i c}^{2}+\mathbf{l}_{i c} \boldsymbol{\lambda}+\delta e_{c}+\varepsilon_{i c}
$$

where $y$ is measured by the natural log of hourly wages or an employment indicator, $\mathbf{x}$ is a vector of individual characteristics (education, age, age squared, marital status, health status, occupation, and industry), $s$ is the number of years since migration, and $\mathbf{l}$ is a vector of dummies indicating various levels of English language ability. With equation (2), estimated separately for

\footnotetext{
${ }^{3}$ While most of the literature on the impact of immigration on local labor markets finds that the effects on natives are small, LaLonde and Topel (1991) and Card (2001) estimate that there are some significant negative effects on immigrant workers.
} 
each identified ethnic group, the parameter $\delta$ would capture the net enclave effect. In other words, this would include the labor market benefits associated with increased information, more efficient job matches, and better employment opportunities along with the costs of increased competition in the local labor market.

This specification may result in biased estimates of the effect of ethnic concentration in an individual's area of residence. One possibility is that those who do not rely on the enclave for employment matches (e.g., high-ability immigrants) will be able to increase their earnings by working outside of their county of residence, even though they choose to reside in the enclave because the benefits derived from $f_{i}\left(e_{c}\right)$ exceed the commuting costs. However, without controlling for work location, it might appear that the ethnic enclave is also providing the labor market benefits. The result is that the estimated $\delta$ will be biased upward. Another (although perhaps less likely) possibility is that the enclave provides labor market benefits to high-skill immigrants, while forcing the low-skill foreign-born to seek work elsewhere. Under these circumstances, the estimated $\delta$ will be biased downward. Several studies have highlighted the importance of this issue (see, for example, Portes and Jensen 1989; Nee et al. 1994; Davis 2004). This can be addressed by modifying equation (2) to include a dummy variable capturing whether an individual works outside of their county of residence. This specification can be expressed as

$$
y_{i c}=\alpha+\mathbf{x}_{i c} \boldsymbol{\beta}+\theta s_{i c}+\varphi s_{i c}^{2}+\mathbf{l}_{i c} \boldsymbol{\lambda}+\phi w_{i c}+\delta e_{c}+\varepsilon_{i c}
$$

where $w$ is a dummy variable indicating whether an individual commutes outside their county of residence for work, and all other variables retain their previous definitions.

Another source of bias would exist if ethnic concentration is affected by metro area 
specific effects that are also correlated with labor market outcomes. As recently discussed in Chowdhury and Pedace (2007), we might suspect that immigrants would choose to locate in metro areas that offer the largest rewards for their skills. On the contrary, however, enclave benefits outside the sphere of the labor market could influence the decision of immigrants to locate in a particular metro area, even in the absence of promising labor market rewards. In either case, failure to control for metro area effects could result in biased estimates of the enclave impact. This suggests that the specification of equation (3) should now be

$$
y_{i c m}=\alpha+\psi_{m}+\mathbf{x}_{i c m} \boldsymbol{\beta}+\theta s_{i c m}+\varphi s_{i c m}^{2}+\mathbf{l}_{i c m} \lambda+\phi w_{i c m}+\delta e_{c m}+\varepsilon_{i c m}
$$

where $\psi_{m}$ represents a metro area fixed effect.

Additionally, it could be argued that ethnic concentration is simply serving as a proxy for unobserved productivity characteristics associated with each ethnic group, as suggested in the work by Borjas (1982) and James et al. (2002). This might include the source country’s education quality, training, cultural awareness, labor market experience, etc. Immigrants belonging to some ethnic groups may have acquired skills that are helpful in making the transition to the U.S. labor market, while others have not. Depending on the nature of the unobserved characteristics, the estimated enclave effects could be biased up or down. In order to address this, we use immigrant workers from all identified ethnic groups and equation (4) to create a D-in-D estimate of the enclave effect. The specification becomes

$$
y_{i c m}=\alpha+\psi_{m}+\mathbf{x}_{i c m} \boldsymbol{\beta}+\theta s_{i c m}+\varphi s_{i c m}^{2}+\mathbf{l}_{i c m} \lambda+\phi w_{i c m}+\mathbf{n}_{i c m} \gamma+\left(\mathbf{n}_{i c m} \mathbf{e}_{c m}\right) \boldsymbol{\delta}+\varepsilon_{i c m}
$$


where $\mathbf{n}$ is a vector of indicators for each ethnic group, ne is a vector of interactions between ethnicity and ethnic concentration, and $\boldsymbol{\delta}$ is subsequently the D-in-D estimator. For the ethnicity indicators, we use the "other" foreign-born group as the base category. This is a group representing immigrants whose countries of origin are geographically dispersed, culturally heterogeneous, and unlikely to form a cohesive enclave. Consequently, the vector $\boldsymbol{\delta}$ will represent the net labor market enclave effect for all of the remaining ethnic groups. ${ }^{4}$

A final concern that should be addressed is endogeneity bias. This issue is relevant if workers choose to locate in areas that offer higher wages and better employment opportunities. If the size of the ethnic enclave is influenced in this manner by variation in wages and employment, then positive correlation with determinants of labor market outcomes that have been relegated to the error term would result in estimated enclave effects that are biased upward. While the behavior of some workers might be characterized by this responsiveness to labor market conditions, a great deal of work on immigrant location decisions suggests that ethnic concentration is likely to be exogenous in wage and employment equations. Bartel (1989), Bartel and Koch (1991), and Zavodny (1997) show that the most important determinant of migration decisions for immigrants is the existing concentration of foreign-born and countrymen in the destination location.

In related work on enclaves, Gonzalez (1998) treats ethnic concentration as exogenous and Chowdhury and Pedace (2007) confirm that there is no significant difference between ordinary least squares (OLS) and instrumental variable (IV) estimates of enclave effects. Consequently, we have chosen to avoid the loss of efficiency associated with unnecessary IV procedures and estimate equations (2) through (5) using OLS when the natural log of the weekly wage is the dependent variable and probit when the employment indicator is the dependent

\footnotetext{
${ }^{4}$ The standard errors for $\boldsymbol{\delta}$ are corrected for the aggregation of $\mathbf{e}$ (see Moulton 1990; Wooldridge 2003).
} 
variable. $^{5}$

\section{Data and Enclave Identification}

This paper utilizes the 1-in-6 2000 Decennial Census Long Form Sample. This data is not public-use, but is available through the Census Bureau's Research Data Centers (RDCs). ${ }^{6}$ We access household and individual data for those residing in states with the largest foreign-born populations; namely, California, Florida, Illinois, New Jersey, New York, and Texas. These 6 states account for 39.3 percent of the total U.S. population and 70.4 percent of the total foreignborn population (Schmidley 2001). Furthermore, there is considerable variation of foreign-born concentration within each of these states since immigrants are not uniformly dispersed.

The analysis includes male and female immigrants aged 16-64 who were living in identifiable counties, county subdivisions, and census tracts. ${ }^{7}$ The wage regression samples are also restricted to the civilian, non-student, wage and salary workers who were working for pay during 1999 and reported all the necessary personal and employment information. The resulting wage analysis sample includes a total of 699,548 male observations and 494,655 female observations. The employment estimates contain a slightly larger sample because they include those who were not employed in 1999 and had no reported earnings; 777,210 males and 554,737 females. Table 1 provides a list and definition of each variable included in the empirical analysis.

\footnotetext{
${ }^{5}$ Some endogeneity tests were conducted with estimates of equation (5). These were consistent with previous work, so we chose not to discuss them further.

${ }^{6}$ However, in order to access the data, the Census Bureau requires that researchers submit a proposal for review, identifying the need for non-public data. Researchers must also successfully pass a background screening, training exercises to obtain Special Sworn Status, and agree to keep data secured at the RDC until the appropriate disclosure (respondent confidentiality) analysis has been performed.

7 County subdivisions are areas within counties that have established local governments, election precincts, or magisterial districts. Census tracts are even smaller geographic areas containing at least 1,500 , but no more than 8,000 residents.
} 
[Insert Table 1]

This particular data is essential to our research goals for two reasons. First, the sample size is large enough to ensure that our ethnicity analysis can include numerous groups and not simply the largest segments (e.g., Mexican). As shown in Table 2, the analysis sample includes a large number of individuals from each of the defined ethnic groups; the smallest group is Cuban females, while the largest group is Mexican males. Second, the level of aggregation for place of residence information (i.e., county, county subdivision, and census tract) is far superior for examining ethnic enclaves. With public-use data, the geographic household location information is typically limited to the metro area, but many ethnic enclaves may co-exist within the boundaries of a metro area, so the 1-in-6 Census sample provides a unique opportunity to examine variation in ethnic concentration within more appropriate geographical units.

\section{[Insert Table 2]}

Table 3 illustrates the more detailed geographic information available using this data in comparison with public-use data. In addition to the 6 states in the sample representing the majority of the immigrant population, the metro areas of Chicago, Los Angeles, Miami, New York, and San Francisco housed 49.8 percent of the foreign-born population (Schmidley 2001). There is a general tendency for immigrants to locate in metro areas and the presence of many ethnic groups can compromise the ability of a metro-level analysis to identify unique enclaves. Although 80 metro areas could be used with public-use data in these states to produce variability 
in the size of ethnic enclaves, in our data there are 564 counties, 4,801 county subdivisions, and 23,484 census tracts to provide more variability both within and between ethnic groups. In comparison to previous research relying on public-use data for household location information, this work represents a significant improvement in the identification of ethnic enclaves.

\section{[Insert Table 3]}

The ethnic concentration measures in Table 4 indicate that immigrants are attracted to larger enclaves or areas that have above average concentrations of the same ethnic group. This pattern holds for all ethnic groups and for both males and females. The importance of enclaves can be shown with calculations of ethnic concentration at the county, county subdivision, and census tract level. For example, the average concentration of Mexicans across counties, county subdivisions, and census tracts for the male sample is $16.1,19.9$, and 65.5 percent, respectively. ${ }^{8}$

\section{[Insert Table 4]}

In general, ethnic concentrations are 3 to 10 times greater at the census tract level compared to the county level. For both males and females, and for all groups, the average and variance of ethnic concentration increases as the level of aggregation is decreased. This suggests that enclaves can be disguised at, the more commonly used, higher levels of aggregation. Next, we estimate the impact of these location decisions and the size of the enclave on wages and employment. The estimated effects at the census tract level are not substantively different from those at the county subdivision level, so these are not discussed in the results section below.

\footnotetext{
${ }^{8}$ The means for the other variables used in the analysis are in the appendix; Tables A1 and A2.
} 


\section{Results}

\section{County Wage Effects}

In Table 5, columns (1)-(4), we present the estimates of the enclave effects for males using county level measures of ethnic concentration. The results in column (1) are estimates of equation (2) and indicate that the net enclave effect varies by ethnicity. For Mexican and Central American workers, an increase in the concentration of their ethnicity tends to be associated with lower earnings, but for East Asian workers the opposite relationship is observed. For all other ethnic groups, the initial results suggest that there is an insignificant relationship for males.

\section{[Insert Table 5]}

In general, the baseline results for males are robust to the inclusion of work-county controls, as seen in column (2). Those who work outside of their county of residence earn higher wages; although the complete set of estimated coefficients are not included in the tables, the work-county controls are significant in the regressions for all ethnic groups. The suspicion that excluding this would overestimate the positive enclave effects is only confirmed with South American workers. For this group, the enclave effect is insignificant without the work-county control, but it becomes negative and significant when this is included. For all other ethnic groups, including the work-county control has an insignificant impact on the estimates.

In column (3), a much larger impact on the results is observed when we control for the metro area location decisions of the immigrant workers. As suspected, failing to control for this leads to an overestimate of positive enclave effects. For all, except Mexican and East Asian 
workers, the inclusion of metro-area controls increases the negative effects associated with the size of the enclave. ${ }^{9}$ For South American workers, the negative enclave effect is almost 50 percent larger. For European workers, an insignificant enclave effect becomes negative and significant. Finally, for East Asian workers, a positive and significant enclave effect becomes insignificant after taking into account the metro area effects.

As hypothesized, the D-in-D estimates of equation (5) suggest that the positive enclave effect is underestimated for some groups and overestimated for others. The results in column (4) imply that the positive enclave effects are particularly underestimated for South American, Puerto Rican, Cuban, and European workers, but overestimated for Central American, West Asian and East Asian workers. For Mexican males, the estimates are not significantly altered with the D-in-D approach.

For males, the net outcome is that the enclave has negative effects on wages for Mexican, Central American, West Asian, and East Asian workers, while having an insignificant impact on the wages of other groups. A 1 standard deviation increase in the concentration of Mexican immigrants reduces the hourly earnings of that ethnic group by 1.7 percent. A slightly smaller effect is observed for East Asian males. For Central American and West Asian males, a 1 standard deviation increase in ethnic concentration reduces wages by 3.4 and 3.5 percent, respectively.

The results in columns (5)-(8) of Table 5 show that the enclave effects for females differ only slightly from the estimates for males. Estimates of equation (2) initially indicate that there are mostly positive or insignificant enclave wage effects. The only significant negative relationships between the size of the ethnic enclave and wages are for Mexican and Central American women. For Puerto Rican and Cuban women, the relationship is not significant, but it

\footnotetext{
${ }^{9}$ Although in some cases, the difference is not significant.
} 
is positive for South Americans, West Asians, East Asians, and Europeans.

In column (6), including work-county controls does not change the negative relationship between the size of the ethnic enclave and earnings for Mexican females. Similarly, the positive effects for West Asian, East Asian, and European women remain. However, the negative effect for Central American women and the positive effect for South American women both become insignificant.

As with males, the positive enclave effects for females also tend to be overestimated without metro area effects. The only exception is Mexican females, where the negative enclave effect remains, but it is significantly smaller with metro area controls included. The metro area effects also have a small impact on the enclave effect for Central American women, where the coefficient remains insignificant. For East Asian and European women, on the other hand, a positive and significant enclave effect becomes statistically insignificant after including metro area effects. A similar result is observed for South American and Puerto Rican women; insignificant enclave effects become negative and significant after controlling for metro area effects. West Asian women experience the largest impact of including metro area effects; a positive and significant enclave effect becomes negative and significant.

Using the D-in-D results, a 1 standard deviation increase in the county ethnic group concentration is associated with a 2.3 percent decrease in hourly wages for Mexican females and about a 1.7 percent decrease for both Central American and West Asian females. Unlike males, however, European females experience positive net enclave effects; a 1 standard deviation increase in the concentration of their ethnic group is related to a 1.8 percent increase in their hourly wages. For South American, Puerto Rican, Cuban, and East Asian females, the net enclave effect is not statistically significant. 


\section{County Subdivision Wage Effects}

Table 6, columns (1)-(4) contain the estimated effects for males using the county subdivision as the level of aggregation in measuring the size of the ethnic enclave. The pattern of the estimated enclave effects is similar, but not identical, to those using the county level of aggregation. Rather than 4, there are now 6 ethnic groups with significant negative enclave effects; these include Mexican, Central American, South American, Puerto Rican, Cuban, and East Asian workers. For West Asians and Europeans, the enclave effects are not significant. While the coefficients on the enclave effects tend to be smaller at the subdivision level, the increased variability in the concentration of each ethnic group results in wage effects that are similar to the county level estimates.

\section{[Insert Table 6]}

In the D-in-D specification of column (4), a 1 standard deviation increase in the county subdivision ethnic concentration is associated with a decrease in hourly earnings of 1.3, 3.9, 2.3, 2.0, 4.1 and 1.2 percent for Mexican, Central American, South American, Puerto Rican, Cuban, and East Asian males, respectively. The direction and magnitude of the effects are mostly consistent with the county-level results, but more statistically significant results are revealed with the county subdivision analysis.

The county subdivision results for females, in Table 6, columns (5)-(8), exhibit an only slightly different pattern. The male estimates of the enclave effects are negative and significant for all groups, except West Asians and Europeans. However, in the female estimates, there are 
three groups with insignificant enclave effects; Puerto Ricans, East Asians, and Europeans. For all other groups, the coefficients are negative and significant in the D-in-D specification. More importantly, as with the male estimates, the county subdivision results suggest that negative enclave effects may be overlooked at higher levels of aggregation. At the county level, there are significant negative effects for Mexican, Central American, and West Asian females. However, with the county subdivision estimates, there are significant negative effects for Mexican, Central American, South American, Cuban, and West Asian females. Furthermore, the positive enclave effect for European females in the county level estimates becomes insignificant in the subdivision results.

The female D-in-D estimates suggest that the largest enclave effects are on Central and South Americans; a 1 standard deviation increase in the concentration of their ethnic group in a county subdivision is associated with a 2.5 and 2.3 percent decrease in hourly wages, respectively. There are smaller effects on Mexican, Cuban and West Asian females; a 1 standard deviation increase in the county subdivision ethnic concentration results in a 1.7 percent decrease in hourly wages for both Mexicans and Cubans and a 1.3 percent decrease in hourly wages for West Asians. Consistent with the results for males, the county subdivision estimates are able to identify additional groups with negative enclave impacts, although the magnitudes remain comparable to the county level estimates.

\section{County Employment Effects}

It is possible that enclave benefits in the labor market are primarily channeled through employment opportunities rather than higher wages. If the enclave serves to diminish the chances of poverty by creating more job matches, then our focus on wages in the previous 
section will understate the importance of ethnic concentration in the economic success of immigrants. This is addressed by estimating a series of probit employment regressions with the same control variables as the wage equations. The dependent employment variable used in this portion of the analysis is equal to 1 if the individual is employed and 0 if unemployed. ${ }^{10}$

In Table 7, columns (1)-(4), the county level enclave effects are reported for males. As with the wage equation estimates, column (1) corresponds to the basic specification, column (2) includes work-county controls, column (3) includes controls for metro area fixed effects, and the D-in-D estimates are in column (4). Unlike the wage equation estimates, the significance of the enclave effect does not increase as we proceed from the basic specification to the inclusion of metro area controls. Although the enclave appears to exert a negative influence on employment probabilities for four ethnic groups in the basic specification, this is true for only two groups (Central Americans and West Asians) once metro area effects are included. The D-in-D results, however, once again imply that some of the effects attributed to ethnic concentration in columns (1) through (3) may be due to ethnicity-specific effects on employment rather than the enclave itself. The enclave effect on West Asians disappears, but negative effects appear for Puerto Ricans and East Asians.

\section{[Insert Table 7]}

The most important similarity between the employment and wage estimates for males is that all of the statistically significant enclave effects are negative. Although the enclave

\footnotetext{
${ }^{10}$ Alternative specifications used the number of weeks worked and the number of hours typically worked in a week as dependent variables. These were estimated with both OLS and Tobit techniques. However, we focus our attention on the probit results because the coefficients in the weeks and hours worked regressions did not substantively change our conclusions about the enclave effects on employment.
} 
employment effects are insignificant for most groups, they are negative for Central American, Puerto Rican, and East Asian males. A 1 standard deviation increase in the county concentration of their ethnicities is associated with a $0.1,0.2$, and 0.2 percent decrease in their employment probabilities, respectively. Even the largest enclave effect has a small impact on employment propensities. It is perhaps most reasonable to interpret the estimates as indicating a negligible net enclave effect on employment for males.

For females, the county level enclave employment estimates are shown in Table 7, columns (5)-(8). These are also generally consistent with the wage equation estimates. Initially, in column (5), negative enclave employment effects are observed for Mexican, Central American, South American, and Puerto Rican females. In the D-in-D estimates, however, only the enclave effect on Puerto Ricans is significant. For this group, a 1 standard deviation increase in the concentration of their ethnicity reduces employment chances by 0.4 percent. On the other hand, for European females, a 1 standard deviation increase in their ethnic concentration is associated with a 0.2 percent increase in employment propensities. Despite a few statistically significant coefficients, as is the case with the male employment estimates, the magnitudes of the effects are trivial.

\section{County Subdivision Employment Effects}

In Table 8, we report the county subdivision enclave effects for males and females. For two reasons it is not necessary to devote much attention to these results after discussing the county level effects. First, the sign and significance of the coefficients for most ethnic groups is similar using the county subdivision level of aggregation. This is true for both males and females. Second, while there are a few changes in measures of statistical significance at the level 
of the county subdivision, the measured impacts of the enclave are quite similar to the county

level estimates. For employment, this implies that the magnitudes of the enclave effects continue to be inconsequential.

\section{[Insert Table 8]}

\section{Conclusions}

The enclave economy hypothesis claims that immigrants benefit by locating in areas that can provide contact with familiar culture, language, and social activities. This view also claims that the ethnic enclave provides a "warm embrace" and creates networks responsible for providing immigrants with job opportunities that are, on average, more desirable than those available to them in the labor market at large. Some early empirical evidence supported this hypothesis, but these studies typically utilized small samples, focused on few ethnic groups, and some contained serious econometric flaws. More recent studies have begun to develop a consensus challenging the enclave economy hypothesis.

The results of this study suggest that enclaves do not provide net economic benefits to wage and salary earners. Although the foreign-born may benefit from social and cultural activities in these enclaves, there are almost no improvements in employment measures and considerable evidence of decreases in wages associated with larger enclaves. In addition, the results highlight the importance of utilizing a lower level of aggregation, such as the county subdivision, for measuring enclaves and ethnic concentration. The overall pattern for both males and females is characterized by more significant negative wage effects using the subdivision as opposed to the county or, as used in other studies, the metro area. 
Consistent with recent work by Chowdhury and Pedace (2007), estimates of the enclave effect are biased without controls for metro area fixed effects. However, unlike their findings, all of the enclave effects do not become insignificant in the D-in-D specification. The pattern of the results in this study, where more coefficients become statistically significant as the geographic area used to define an enclave is reduced, suggests that their result is likely due to the use of less appropriate levels of aggregation. Even though some of our estimated impacts are small, at a minimum they imply that positive network effects from the enclave are likely offset by negative labor market competition effects. Moreover, the results sharply contrast with the enclave hypothesis view.

Many countries, including Canada, the U.S., and several in Europe have implemented polices for refugee immigrant dispersal. There is a significant difference in the implementation of these policies between North American and European countries. Canada and the U.S. have relied on volunteer agencies, such as churches and community groups, to assist in initial placement and integration efforts, while some European countries have been more explicit by tying housing subsidies to government placement. Nevertheless, there is no evidence indicating that any of these governments have monitored the success of the policies in achieving long-term dispersal of refugees. The results of this study imply that governments should be more cognizant of location patterns for all immigrants (not only refugees) and might benefit by implementing dispersal policies that include incentives supporting labor market assimilation such as language acquisition, education, training, and job placement.

This could have additional implications for public housing communities, which have been traditionally located in inner-cities where immigrant concentrations are highest. Public housing policy should consider the impact of housing concentration on enclave formation and 
the subsequent effect on poverty concentration. Finally, the results also highlight an additional factor that should be considered in general immigration reform policy. Temporary work programs, such as those recently debated in Congress for example, typically result in larger concentrations of immigrants in one or two industries and in few, well-defined geographic areas. While enclaves may provide the desired social benefits for temporary workers, our results suggest that we must pay close attention to the downward wage pressures that some immigrant groups may experience if geographical dispersion is minimal among these temporary migrants. 


\section{References}

Bartel, Ann P. 1989. Where do the new U.S. immigrants live? Journal of Labor Economics, Vol. 7, No. 4 (October), 371-91.

Bartel, Ann P. and Marianne J. Koch. 1991. Internal migration of U.S. immigrants. In Immigration, Trade, and the Labor Market, ed. John M. Abowd and Richard B. Freeman. Chicago, IL: University of Chicago Press.

Borjas, George J. 1982. The earnings of male hispanic immigrants in the United States. Industrial and Labor Relations Review, Vol. 35, No. 3 (April), 343-53. . 1995. Assimilation and changes in cohort quality revisited: what happened to immigrant earnings in the 1980s. Journal of Labor Economics, Vol. 13, No. 2 (April), 201-45.

Card, David. 2001. Immigrant inflows, native outflows, and the local labor market impacts of higher immigration. Journal of Labor Economics, Vol. 19, No. 1 (January), 22-64.

Chiswick, Barry R. and Paul W. Miller. 2005. Do enclaves matter in immigrant adjustment? City and Community, Vol. 4, No. 1 (March), 5-35.

Chowdhury, Mussaddeq and Roberto Pedace. 2007. Ethnic enclaves and labor markets: an analysis of immigrant outcomes in California. Contemporary Economic Policy, Vol. 25, No. 2 (April), 238-49.

Davis, Carla P. 2004. Beyond Miami: the ethnic enclave and personal income in various Cuban communities in the United States. International Migration Review, Vol. 38, No. 2 (Summer), 450-69.

Edin, Per-Anders, Peter Fredriksson, and Olof Aslund. 2003. Ethnic enclaves and the economic success of immigrants - evidence from a natural experiment. Quarterly Journal of 
Economics, Vol. 118, No. 1 (February), 329-57.

Funkhouser, Edward. 2000. Changes in the geographic concentration and location of residence of immigrants. International Migration Review, Vol. 34, No. 2 (Summer), 489-510.

Gonzalez, Arturo. 1998. Mexican enclaves and the price of culture. Journal of Urban Economics, Vol. 43, No. 2 (March), 273-91.

James, Franklin J., Jeff Romine, and Phyllis Resnick Terry. 2002. Big city labor markets and immigrant economic performance. Policy Studies Journal, Vol. 30, No. 1, 107-31.

LaLonde, Robert J. and Robert H. Topel. 1991. Labor market adjustments to increased immigration. In Immigration, Trade, and the Labor Market, ed. John M. Abowd and Richard B. Freeman. Chicago, IL: University of Chicago Press.

Mar, Don. 1991. Another look at the enclave economy thesis: Chinese immigrants in the ethnic labor market. Amerasia Journal, Vol. 17, No. 3 (Fall), 5-21.

Moulton, Brent R. 1990. An illustration of a pitfall in estimating the effects of aggregate variables on micro units. Review of Economics and Statistics, Vol. 72, No. 2 (May), 3348.

Nee, Victor, Jimy M. Sanders, and Scott Sernau. 1994. Job transitions in an immigrant metropolis: ethnic boundaries and the mixed economy. American Sociological Review, Vol. 59, No. 6 (December), 849-72.

Portes, Alejandro and Leif Jensen. 1989. The enclave and the entrants: patterns of ethnic enterprise in Miami before and after Mariel. American Sociological Review, Vol. 54, No. 6 (December), 929-49.

Sanders, Jimy M. and Victor Nee. 1987. Limits of ethnic solidarity in the enclave economy. American Sociological Review, Vol. 52, No. 6 (December), 745-73. 
Schmidley, Dianne A. 2001. Profile of the foreign-born population in the United States: 2000. U.S. Census Bureau Current Population Reports, P23-206. Washington DC: U.S. Government Printing Office.

Wilson, Kenneth L. and Alejandro Portes. 1980. Immigrant enclaves: an analysis of the labor market experiences of Cubans in Miami. American Journal of Sociology, Vol. 86, No. 2 (September), 295-319.

Wooldridge, Jeffrey M. 2003. Cluster-sample methods in applied econometrics. American Economic Review, Vol. 93, No. 2 (May), 133-8.

Zavodny, Madeline. 1997. Welfare and the locational choices of new immigrants. Economic Review, Federal Reserve Bank of Dallas, Second Quarter, 2-10.

Zhou, Min and John R. Logan. 1989. Returns on human capital in ethnic enclaves: New York City’s Chinatown. American Sociological Review, Vol. 54, No. 5 (October), 809-20. 
Table 1

ANALYSIS VARIABLE LIST AND DEFINITIONS

\begin{tabular}{|c|c|}
\hline Name & Definition \\
\hline \multicolumn{2}{|c|}{ DEPENDENT VARIABLES } \\
\hline lnhrwage & natural log of the hourly wage \\
\hline employed & 1 if employed, 0 if unemployed \\
\hline \multicolumn{2}{|c|}{ EXPLANATORY VARIABLES } \\
\hline \multicolumn{2}{|l|}{ Ethnicity concentration } \\
\hline cnty\%mex & percent of county residents born in Mexico \\
\hline cnty\%centam & percent of county residents born in Central America \\
\hline cnty\%southam & percent of county residents born in South America \\
\hline cnty\%puertric & percent of county residents born in Puerto Rico \\
\hline cnty\%cuba & percent of county residents born in Cuba \\
\hline cnty\%wasia & percent of county residents born in West Asia \\
\hline cnty\%easia & percent of county residents born in East Asia \\
\hline cnty\%europe & percent of county residents born in Europe \\
\hline cntysub\%mex & percent of county subdivision residents born in Mexico \\
\hline cntysub\%centam & percent of county subdivision residents born in Central America \\
\hline cntysub\%southam & percent of county subdivision residents born in South America \\
\hline cntysub\%puertric & percent of county subdivision residents born in Puerto Rico \\
\hline cntysub\%cuba & percent of county subdivision residents born in Cuba \\
\hline cntysub\%wasia & percent of county subdivision residents born in West Asia \\
\hline cntysub\%easia & percent of county subdivision residents born in East Asia \\
\hline cntysub\%europe & percent of county subdivision residents born in Europe \\
\hline \multicolumn{2}{|l|}{ Education } \\
\hline grade $<1$ & completed less than $1^{\text {st }}$ grade, base category \\
\hline grade1-4 & 1 if completed grade between $1^{\text {st }}$ and $4^{\text {th }}, 0$ otherwise \\
\hline grade5-8 & 1 if completed grade between $5^{\text {th }}$ and $8^{\text {th }}, 0$ otherwise \\
\hline grade9-11 & 1 if completed grade between $9^{\text {th }}$ and $11^{\text {th }}, 0$ otherwise \\
\hline hsgraduate & 1 if completed high school, 0 otherwise \\
\hline somecoll & 1 if completed some college, 0 otherwise \\
\hline assocdeg & 1 if completed associate's degree, 0 otherwise \\
\hline bachdeg & 1 if completed bachelor's degree, 0 otherwise \\
\hline mastdeg & 1 if completed master's degree, 0 otherwise \\
\hline profdeg & 1 if completed professional degree, 0 otherwise \\
\hline doctdeg & 1 if completed Ph.D., 0 otherwise \\
\hline \multicolumn{2}{|l|}{ Age } \\
\hline age & Age \\
\hline agesq & age squared \\
\hline \multicolumn{2}{|l|}{ Marital status } \\
\hline nvrmar & never married, base category \\
\hline married & 1 if married, 0 otherwise \\
\hline widow & 1 if a widow, 0 otherwise \\
\hline
\end{tabular}


divsep

Disability

nodiswrk

disabwrk

English ability

onlyeng

goodeng

pooreng

noeng

Residence time

ysm

ysmsq

Work location

wkincnty

wkoutcnty
1 if divorced or separated, 0 otherwise

no disability limiting work, base category

1 if disability limits work, 0 otherwise

1 if speak only English, 0 otherwise

1 if speak good English, 0 otherwise

1 if speak poor English, 0 otherwise

no English speaking ability, base category

years since migrating to the United States

years since migrating to the United States squared

work in county of residence, base category

1 if work outside of residence county, 0 otherwise

Note- Additional explanatory variables include industry, occupation, and, in some cases, metro area and ethnic group indicators. 


\section{Table 2}

SAMPLE ETHNICITY AND SEX DISTRIBUTION

\begin{tabular}{lcccc}
\hline Ethnic Group & Male: & & \multicolumn{2}{c}{ Female: } \\
Wage Sample & Employment Sample & Wage Sample & Employment Sample \\
\hline Mexican & 247,269 & 275,280 & 275,280 & 134,791 \\
Central American & 45,453 & 49,688 & 31,939 & 37,084 \\
South American & 40,824 & 44,985 & 33,074 & 37,487 \\
Puerto Rican & 20,524 & 21,616 & 17,685 & 18,933 \\
Cuban & 7,849 & 8,234 & 6,086 & 6,211 \\
West Asian & 68,274 & 76,230 & 39,690 & 43,637 \\
East Asian & 116,767 & 128,939 & 115,415 & 126,924 \\
European & 87,535 & 96,781 & 73,576 & 81,204 \\
Other Foreign-Born & 65,053 & 75,457 & 60,702 & 68,466 \\
Total Observations & 699,548 & 777,210 & 494,655 & 554,737 \\
\hline
\end{tabular}




\section{Table 3}

STATE GEOGRAPHIC CHARACTERISTICS

\begin{tabular}{lcccccc}
\hline & $\begin{array}{l}\text { State: } \\
\text { California }\end{array}$ & Florida & Illinois & New Jersey & New York & Texas \\
\hline Metro Areas & 16 & 19 & 9 & 2 & 10 & 24 \\
Counties & 58 & 67 & 102 & 21 & 62 & 254 \\
County Subdivisions & 386 & 293 & 1,679 & 567 & 1,013 & 863 \\
Census Tracts & 6,978 & 2,771 & 2,743 & 1,915 & 4,746 & 4,331 \\
Total Observations & 563,739 & 104,215 & 104,719 & 111,879 & 251,371 & 196,024 \\
\hline
\end{tabular}




\section{Table 4}

\section{MEANS AND STANDARD DEVIATIONS OF ETHNICITY CONCENTRATION BY LEVEL OF AGGREGATION}

\begin{tabular}{lcccccc}
\hline & Male: & & & Female: & & \\
Ethnic Group & County & County Subdivision & Census Tract & County & County Subdivision & Census Tract \\
\hline \multirow{3}{*}{ Mexican } & & & & & & \\
& 16.12 & 19.93 & 65.53 & 17.42 & 21.23 & 64.85 \\
Central American & $(8.86)$ & $(14.08)$ & $(26.42)$ & $(9.31)$ & $(14.34)$ & $(27.11)$ \\
& 3.57 & 4.84 & 19.21 & 3.64 & 4.71 & 17.63 \\
South American & $(2.69)$ & $(4.29)$ & $(15.62)$ & $(2.76)$ & $(4.26)$ & $(15.19)$ \\
& 5.26 & 6.36 & 19.59 & 5.03 & 5.96 & 18.42 \\
Puerto Rican & $(5.08)$ & $(6.44)$ & $(15.14)$ & $(5.01)$ & $(6.29)$ & $(14.47)$ \\
& 3.03 & 3.94 & 16.86 & 3.15 & 4.07 & 17.39 \\
Cuban & $(3.63)$ & $(4.42)$ & $(15.72)$ & $(3.70)$ & $(4.47)$ & $(15.95)$ \\
& 1.13 & 2.32 & 11.04 & 1.12 & 2.31 & 10.90 \\
West Asian & $(1.48)$ & $(3.83)$ & $(12.60)$ & $(1.48)$ & $(3.85)$ & $(12.49)$ \\
& 3.60 & 5.16 & 25.14 & 3.64 & 5.50 & 26.92 \\
East Asian & $(2.81)$ & $(5.12)$ & $(17.46)$ & $(2.78)$ & $(5.50)$ & $(18.30)$ \\
European & 8.90 & 11.03 & 41.03 & 8.75 & 10.73 & 39.95 \\
& $(5.88)$ & $(8.66)$ & $(23.19)$ & $(5.90)$ & $(8.63)$ & $(23.14)$ \\
& 4.28 & 5.00 & 32.58 & 4.16 & 4.83 & 32.44 \\
& $(2.86)$ & $(4.36)$ & $(20.46)$ & $(2.89)$ & $(4.28)$ & $(20.61)$
\end{tabular}

Note- Conditioning on each ethnic group, concentration is measured as a percentage of the ethnic group population to the total population. Standard deviations are in parentheses. 


\section{Table 5}

\section{COUNTY ENCLAVE WAGE EFFECTS}

\begin{tabular}{|c|c|c|c|c|c|c|c|c|}
\hline Ethnic Group/Variable & $\begin{array}{c}\text { Males: } \\
(1)\end{array}$ & $(2)$ & (3) & (4) & $\begin{array}{c}\text { Females: } \\
(5)\end{array}$ & (6) & $(7)$ & $(8)$ \\
\hline cnty\%mex & $\begin{array}{c}-.0049^{* * *} \\
(.0013)\end{array}$ & $\begin{array}{c}-.0045^{* * *} \\
(.0013)\end{array}$ & $\begin{array}{l}-.0015^{* *} \\
(.0007)\end{array}$ & $\begin{array}{c}-.0019^{* *} \\
(.0009)\end{array}$ & $\begin{array}{c}-.0053^{* * *} \\
(.0012)\end{array}$ & $\begin{array}{c}-.0051^{* * *} \\
(.0013)\end{array}$ & $\begin{array}{l}-.0014^{* *} \\
(.0007)\end{array}$ & $\begin{array}{c}-.0025^{* * *} \\
(.0008)\end{array}$ \\
\hline cnty\%centam & $\begin{array}{c}-.0137^{* * * *} \\
(.0022)\end{array}$ & $\begin{array}{c}-.0103^{* * *} \\
(.0021)\end{array}$ & $\begin{array}{c}-.0105^{* * *} \\
(.0022)\end{array}$ & $\begin{array}{c}-.0127^{* * *} \\
(.0016)\end{array}$ & $\begin{array}{c}-.0058^{* *} \\
(.0023)\end{array}$ & $\begin{array}{c}-.0026 \\
(.0019)\end{array}$ & $\begin{array}{l}-.0010 \\
(.0022)\end{array}$ & $\begin{array}{c}-.0064^{* * *} \\
(.0015)\end{array}$ \\
\hline cnty\%southam & $\begin{array}{l}-.0014 \\
(.0009)\end{array}$ & $\begin{array}{c}-.0037^{* * *} \\
(.0008)\end{array}$ & $\begin{array}{c}-.0055^{* * *} \\
(.0021)\end{array}$ & $\begin{array}{l}-.0034 \\
(.0021)\end{array}$ & $\begin{array}{l}.0031^{* * *} \\
(.0015)\end{array}$ & $\begin{array}{c}.0007 \\
(.0015)\end{array}$ & $\begin{array}{c}-.0056^{* * *} \\
(.0019)\end{array}$ & $\begin{array}{l}-.0027 \\
(.0018)\end{array}$ \\
\hline cnty\%puertric & $\begin{array}{l}-.0020 \\
(.0051)\end{array}$ & $\begin{array}{l}-.0044 \\
(.0048)\end{array}$ & $\begin{array}{c}-.0070^{* * *} \\
(.0024)\end{array}$ & $\begin{array}{l}-.0027 \\
(.0033)\end{array}$ & $\begin{array}{c}.0033 \\
(.0048)\end{array}$ & $\begin{array}{c}.0010 \\
(.0046)\end{array}$ & $\begin{array}{c}-.0035^{* *} \\
(.0016)\end{array}$ & $\begin{array}{l}-.0017 \\
(.0021)\end{array}$ \\
\hline cnty\%cuba & $\begin{array}{c}-.0207^{* * *} \\
(.0056)\end{array}$ & $\begin{array}{c}-.0216^{* * *} \\
(.0047)\end{array}$ & $\begin{array}{l}-.0234^{*} \\
(.0121)\end{array}$ & $\begin{array}{l}-.0192 \\
(.0121)\end{array}$ & $\begin{array}{l}-.0132 \\
(.0106)\end{array}$ & $\begin{array}{l}-.0139 \\
(.0091)\end{array}$ & $\begin{array}{l}-.0063 \\
(.0080)\end{array}$ & $\begin{array}{l}-.0068 \\
(.0045)\end{array}$ \\
\hline cnty\%wasia & $\begin{array}{c}.0029 \\
(.0084)\end{array}$ & $\begin{array}{c}.0001 \\
(.0093)\end{array}$ & $\begin{array}{l}-.0109 \\
(.0067)\end{array}$ & $\begin{array}{l}-.0123^{*} \\
(.0074)\end{array}$ & $\begin{array}{l}.0137^{* * *} \\
(.0044)\end{array}$ & $\begin{array}{l}.0103^{* *} \\
(.0050)\end{array}$ & $\begin{array}{l}-.0078^{*} \\
(.0042)\end{array}$ & $\begin{array}{l}-.0061^{*} \\
(.0036)\end{array}$ \\
\hline cnty\%easia & $\begin{array}{l}.0074^{* * * *} \\
(.0020)\end{array}$ & $\begin{array}{l}.0077^{* * *} \\
(.0022)\end{array}$ & $\begin{array}{l}-.0003 \\
(.0027)\end{array}$ & $\begin{array}{l}-.0026^{*} \\
(.0015)\end{array}$ & $\begin{array}{l}.0081^{* * *} \\
(.0016)\end{array}$ & $\begin{array}{l}.0084^{* * *} \\
(.0017)\end{array}$ & $\begin{array}{c}.0031 \\
(.0019)\end{array}$ & $\begin{array}{l}-.0015 \\
(.0014)\end{array}$ \\
\hline cnty\%europe & $\begin{array}{c}.0080 \\
(.0099)\end{array}$ & $\begin{array}{c}.0048 \\
(.0101)\end{array}$ & $\begin{array}{l}-.0193^{* *} \\
(.0091)\end{array}$ & $\begin{array}{c}.0039 \\
(.0049)\end{array}$ & $\begin{array}{l}.0221^{* * *} \\
(.0076)\end{array}$ & $\begin{array}{l}.0190^{* *} \\
(.0078)\end{array}$ & $\begin{array}{l}-.0049 \\
(.0077)\end{array}$ & $\begin{array}{l}.0063^{*} \\
(.0038)\end{array}$ \\
\hline $\begin{array}{l}\text { Additional Controls: } \\
\text { wkoutcnty }\end{array}$ & no & yes & yes & yes & no & yes & yes & yes \\
\hline metro area effects & no & no & yes & yes & no & no & yes & yes \\
\hline D-in-D estimator & no & no & no & yes & no & no & no & yes \\
\hline
\end{tabular}

Note- The dependent variable is the natural log of the hourly wage. Robust, cluster-adjusted standard errors are in parentheses. All regressions also include education, age, marital status, disability, industry, occupation, and years since migration controls. Columns (3), (4), (7), and (8) include metro area indicators. Columns (4) and (8) also include ethnic group indicators. The coefficients in columns (4) and (8) represent the D-in-D estimates, so they correspond to the interaction of ethnic concentration with the respective ethnic group indicator.

$* p<.10 .{ }^{* *} p<.05 . * * * p<.01$. 


\section{Table 6}

\section{COUNTY SUBDIVISION ENCLAVE WAGE EFFECTS}

\begin{tabular}{|c|c|c|c|c|c|c|c|c|}
\hline Ethnic Group/Variable & $\begin{array}{c}\text { Males: } \\
(1)\end{array}$ & $(2)$ & (3) & (4) & $\begin{array}{c}\text { Females: } \\
(5)\end{array}$ & (6) & $(7)$ & (8) \\
\hline cntysub\%mex & $\begin{array}{c}-.0019^{* * *} \\
(.0007)\end{array}$ & $\begin{array}{c}-.0017^{* * *} \\
(.0007)\end{array}$ & $\begin{array}{c}-.0007^{* * *} \\
(.0002)\end{array}$ & $\begin{array}{c}-.0009^{* * *} \\
(.0003)\end{array}$ & $\begin{array}{c}-.0024^{* * *} \\
(.0008)\end{array}$ & $\begin{array}{c}-.0022^{* * *} \\
(.0008)\end{array}$ & $\begin{array}{c}-.0010^{* * *} \\
(.0002)\end{array}$ & $\begin{array}{c}-.0012^{* * *} \\
(.0003)\end{array}$ \\
\hline cntysub\%centam & $\begin{array}{c}-.0086^{* * * *} \\
(.0024)\end{array}$ & $\begin{array}{c}-.0071^{* * * *} \\
(.0019)\end{array}$ & $\begin{array}{c}-.0079^{* * *} \\
(.0016)\end{array}$ & $\begin{array}{c}-.0090^{* * *} \\
(.0012)\end{array}$ & $\begin{array}{c}-.0049^{* * * *} \\
(.0015)\end{array}$ & $\begin{array}{c}-.0034^{* * * *} \\
(.0012)\end{array}$ & $\begin{array}{c}-.0048^{* * *} \\
(.0009)\end{array}$ & $\begin{array}{c}-.0059^{* * * *} \\
(.0007)\end{array}$ \\
\hline cntysub\%southam & $\begin{array}{l}-.0010 \\
(.0008)\end{array}$ & $\begin{array}{c}-.0026^{* * *} \\
(.0008)\end{array}$ & $\begin{array}{c}-.0043^{* * *} \\
(.0011)\end{array}$ & $\begin{array}{c}-.0036^{* * *} \\
(.0013)\end{array}$ & $\begin{array}{c}.0010 \\
(.0017)\end{array}$ & $\begin{array}{l}-.0007 \\
(.0015)\end{array}$ & $\begin{array}{c}-.0054^{* * * *} \\
(.0012)\end{array}$ & $\begin{array}{c}-.0036^{* * * *} \\
(.0014)\end{array}$ \\
\hline cntysub\%puertric & $\begin{array}{l}-.0030 \\
(.0034)\end{array}$ & $\begin{array}{l}-.0045 \\
(.0029)\end{array}$ & $\begin{array}{c}-.0073^{* * *} \\
(.0016)\end{array}$ & $\begin{array}{l}-.0045^{*} \\
(.0025)\end{array}$ & $\begin{array}{l}.0012 \\
(.0037)\end{array}$ & $\begin{array}{l}-.0001 \\
(.0033)\end{array}$ & $\begin{array}{c}-.0039^{* * *} \\
(.0012)\end{array}$ & $\begin{array}{l}-.0029 \\
(.0018)\end{array}$ \\
\hline cntysub\%cuba & $\begin{array}{c}-.0060^{* * * *} \\
(.0022)\end{array}$ & $\begin{array}{c}-.0079^{* * *} \\
(.0018)\end{array}$ & $\begin{array}{c}-.0116^{* * *} \\
(.0026)\end{array}$ & $\begin{array}{c}-.0109^{* * *} \\
(.0029)\end{array}$ & $\begin{array}{l}-.0019 \\
(.0029)\end{array}$ & $\begin{array}{l}-.0035 \\
(.0030)\end{array}$ & $\begin{array}{c}-.0054^{* * *} \\
(.0014)\end{array}$ & $\begin{array}{c}-.0045^{* * *} \\
(.0012)\end{array}$ \\
\hline cntysub\%wasia & $\begin{array}{c}.0017 \\
(.0033)\end{array}$ & $\begin{array}{c}.0011 \\
(.0029)\end{array}$ & $\begin{array}{l}-.0014 \\
(.0019)\end{array}$ & $\begin{array}{l}-.0031 \\
(.0026)\end{array}$ & $\begin{array}{l}.0017 \\
(.0031)\end{array}$ & $\begin{array}{l}.0014 \\
(.0025)\end{array}$ & $\begin{array}{l}-.0018^{*} \\
(.0010)\end{array}$ & $\begin{array}{c}-.0024^{* *} \\
(.0011)\end{array}$ \\
\hline cntysub\%easia & $\begin{array}{c}.0032 \\
(.0024)\end{array}$ & $\begin{array}{c}.0033 \\
(.0024)\end{array}$ & $\begin{array}{l}-.0008 \\
(.0009)\end{array}$ & $\begin{array}{l}-.0014^{*} \\
(.0008)\end{array}$ & $\begin{array}{c}.0035 \\
(.0023)\end{array}$ & $\begin{array}{c}.0036 \\
(.0023)\end{array}$ & $\begin{array}{l}-.0004 \\
(.0010)\end{array}$ & $\begin{array}{l}-.0011 \\
(.0007)\end{array}$ \\
\hline cntysub\%europe & $\begin{array}{c}.0040 \\
(.0031)\end{array}$ & $\begin{array}{l}.0025 \\
(.0032)\end{array}$ & $\begin{array}{l}-.0049 \\
(.0033)\end{array}$ & $\begin{array}{c}.0006 \\
(.0020)\end{array}$ & $\begin{array}{l}.0097^{* * *} \\
(.0033)\end{array}$ & $\begin{array}{l}.0080^{* * *} \\
(.0030)\end{array}$ & $\begin{array}{l}-.0017 \\
(.0023)\end{array}$ & $\begin{array}{c}.0021 \\
(.0016)\end{array}$ \\
\hline $\begin{array}{l}\text { Additional Controls: } \\
\text { wkoutcnty }\end{array}$ & no & yes & yes & yes & no & yes & yes & yes \\
\hline metro area effects & no & no & yes & yes & no & no & yes & yes \\
\hline D-in-D estimator & no & no & no & yes & no & no & no & yes \\
\hline
\end{tabular}

Note- The dependent variable is the natural log of the hourly wage. Robust, cluster-adjusted standard errors are in parentheses. All regressions also include education, age, marital status, disability, industry, occupation, and years since migration controls. Columns (3), (4), (7), and (8) include metro area indicators. Columns (4) and (8) also include ethnic group indicators. The coefficients in columns (4) and (8) represent the D-in-D estimates, so they correspond to the interaction of ethnic concentration with the respective ethnic group indicator.

$* p<.10 .{ }^{* *} p<.05 . * * * p<.01$. 
Table 7

COUNTY ENCLAVE EMPLOYMENT EFFECTS

\begin{tabular}{|c|c|c|c|c|c|c|c|c|}
\hline Ethnic Group/Variable & $\begin{array}{c}\text { Males: } \\
(1)\end{array}$ & $(2)$ & (3) & (4) & $\begin{array}{c}\text { Females: } \\
(5)\end{array}$ & (6) & $(7)$ & $(8)$ \\
\hline cnty\%mex & $\begin{array}{l}-.0005 \\
(.0009)\end{array}$ & $\begin{array}{l}-.0004 \\
(.0009)\end{array}$ & $\begin{array}{l}-.0003 \\
(.0014)\end{array}$ & $\begin{array}{l}-.0001 \\
(.0009)\end{array}$ & $\begin{array}{c}-.0025^{* * *} \\
(.0007)\end{array}$ & $\begin{array}{c}-.0023^{* * *} \\
(.0007)\end{array}$ & $\begin{array}{c}.0006 \\
(.0015)\end{array}$ & $\begin{array}{c}.0005 \\
(.0007)\end{array}$ \\
\hline cnty\%centam & $\begin{array}{c}-.0154^{* * *} \\
(.0036)\end{array}$ & $\begin{array}{c}-.0167^{* * *} \\
(.0037)\end{array}$ & $\begin{array}{c}-.0174^{* * *} \\
(.0066)\end{array}$ & $\begin{array}{l}-.0068^{*} \\
(.0042)\end{array}$ & $\begin{array}{l}-.0057^{*} \\
(.0030)\end{array}$ & $\begin{array}{l}-.0050 \\
(.0034)\end{array}$ & $\begin{array}{l}-.0044 \\
(.0040)\end{array}$ & $\begin{array}{c}.0047 \\
(.0042)\end{array}$ \\
\hline cnty\%southam & $\begin{array}{l}-.0026 \\
(.0016)\end{array}$ & $\begin{array}{c}-.0051^{* * *} \\
(.0018)\end{array}$ & $\begin{array}{l}-.0044 \\
(.0031)\end{array}$ & $\begin{array}{c}.0005 \\
(.0022)\end{array}$ & $\begin{array}{c}-.0039^{* *} \\
(.0017)\end{array}$ & $\begin{array}{c}-.0047^{* *} \\
(.0021)\end{array}$ & $\begin{array}{l}-.0033 \\
(.0037)\end{array}$ & $\begin{array}{l}-.0018 \\
(.0026)\end{array}$ \\
\hline cnty\%puertric & $\begin{array}{c}-.0078^{* *} \\
(.0035)\end{array}$ & $\begin{array}{c}-.0110^{* * *} \\
(.0039)\end{array}$ & $\begin{array}{l}-.0078 \\
(.0058)\end{array}$ & $\begin{array}{l}-.0089^{*} \\
(.0047)\end{array}$ & $\begin{array}{l}-.0104^{*} \\
(.0064)\end{array}$ & $\begin{array}{l}-.0120^{*} \\
(.0065)\end{array}$ & $\begin{array}{c}-.0119^{* * *} \\
(.0061)\end{array}$ & $\begin{array}{c}-.0141^{* * *} \\
(.0058)\end{array}$ \\
\hline cnty\%cuba & $\begin{array}{c}.0210 \\
(.0192)\end{array}$ & $\begin{array}{c}.0208 \\
(.0207)\end{array}$ & $\begin{array}{l}-.0448 \\
(.0328)\end{array}$ & $\begin{array}{c}.0103 \\
(.0190)\end{array}$ & $\begin{array}{l}-.0214 \\
(.0316)\end{array}$ & $\begin{array}{c}-.0222 \\
(.0325)\end{array}$ & $\begin{array}{l}-.0272 \\
(.0418)\end{array}$ & $\begin{array}{l}-.0357 \\
(.0320)\end{array}$ \\
\hline cnty\%wasia & $\begin{array}{c}-.0118^{* *} \\
(.0057)\end{array}$ & $\begin{array}{c}-.0165^{* * * *} \\
(.0050)\end{array}$ & $\begin{array}{c}-.0212^{* * * *} \\
(.0056)\end{array}$ & $\begin{array}{l}-.0099 \\
(.0062)\end{array}$ & $\begin{array}{c}.0004 \\
(.0041)\end{array}$ & $\begin{array}{l}-.0035 \\
(.0046)\end{array}$ & $\begin{array}{l}-.0073 \\
(.0059)\end{array}$ & $\begin{array}{l}-.0034 \\
(.0034)\end{array}$ \\
\hline cnty\%easia & $\begin{array}{c}-.0043^{* * *} \\
(.0012)\end{array}$ & $\begin{array}{c}-.0042^{* * *} \\
(.0012)\end{array}$ & $\begin{array}{l}-.0030 \\
(.0029)\end{array}$ & $\begin{array}{c}-.0041^{* * *} \\
(.0015)\end{array}$ & $\begin{array}{c}.0003 \\
(.0026)\end{array}$ & $\begin{array}{c}.0004 \\
(.0026)\end{array}$ & $\begin{array}{c}.0023 \\
(.0032)\end{array}$ & $\begin{array}{l}.0006 \\
(.0019)\end{array}$ \\
\hline cnty\%europe & $\begin{array}{c}-.0058 \\
(.0073)\end{array}$ & $\begin{array}{l}-.0076 \\
(.0075)\end{array}$ & $\begin{array}{c}-.0086 \\
(.0067)\end{array}$ & $\begin{array}{l}-.0038 \\
(.0052)\end{array}$ & $\begin{array}{c}.0075 \\
(.0064)\end{array}$ & $\begin{array}{c}.0058 \\
(.0069)\end{array}$ & $\begin{array}{c}.0107 \\
(.0067)\end{array}$ & $\begin{array}{l}.0091^{*} \\
(.0048)\end{array}$ \\
\hline
\end{tabular}

Additional Controls:

metro area effects

D-in-D estimator

$\begin{array}{lccccccc}\text { no } & \text { yes } & \text { yes } & \text { yes } & \text { no } & \text { yes } & \text { yes } & \text { yes } \\ \text { no } & \text { no } & \text { yes } & \text { yes } & \text { no } & \text { no } & \text { yes } & \text { yes } \\ \text { no } & \text { no } & \text { no } & \text { yes } & \text { no } & \text { no } & \text { no } & \text { yes }\end{array}$

Note- The dependent variable is equal to 1 if individual is employed; 0 if unemployed. Robust, cluster-adjusted standard errors are in parentheses. All regressions also include education, age, marital status, disability, industry, occupation, and years since migration controls. Columns (3), (4), (7), and (8) include metro area indicators. Columns (4) and (8) also include ethnic group indicators. The coefficients in columns (4) and (8) represent the D-in-D estimates, so they correspond to the interaction of ethnic concentration with the respective ethnic group indicator.

$* p<.10$. ** $p<.05$. *** $p<.01$. 


\section{Table 8}

\section{COUNTY SUBDIVISION ENCLAVE EMPLOYMENT EFFECTS}

\begin{tabular}{|c|c|c|c|c|c|c|c|c|}
\hline Ethnic Group/Variable & $\begin{array}{c}\text { Males: } \\
(1)\end{array}$ & $(2)$ & (3) & (4) & $\begin{array}{c}\text { Females: } \\
(5)\end{array}$ & $(6)$ & $(7)$ & $(8)$ \\
\hline cntysub\%mex & $\begin{array}{l}-.0005 \\
(.0005)\end{array}$ & $\begin{array}{c}-.0004 \\
(.0005)\end{array}$ & $\begin{array}{c}-.0002 \\
(.0005)\end{array}$ & $\begin{array}{l}-.0002 \\
(.0004)\end{array}$ & $\begin{array}{c}-.0012^{* *} \\
(.0005)\end{array}$ & $\begin{array}{c}-.0011^{* *} \\
(.0005)\end{array}$ & $\begin{array}{c}-.0002 \\
(.0009)\end{array}$ & $\begin{array}{c}-.0001 \\
(.0008)\end{array}$ \\
\hline cntysub\%centam & $\begin{array}{c}-.0083^{* * *} \\
(.0028)\end{array}$ & $\begin{array}{c}-.0086^{* * *} \\
(.0029)\end{array}$ & $\begin{array}{c}-.0089^{* *} \\
(.0039)\end{array}$ & $\begin{array}{l}-.0039 \\
(.0025)\end{array}$ & $\begin{array}{c}-.0050^{* *} \\
(.0022)\end{array}$ & $\begin{array}{c}-.0048^{* *} \\
(.0023)\end{array}$ & $\begin{array}{l}-.0024 \\
(.0020)\end{array}$ & $\begin{array}{c}.0003 \\
(.0029)\end{array}$ \\
\hline cntysub\%southam & $\begin{array}{l}-.0006 \\
(.0018)\end{array}$ & $\begin{array}{c}-.0021 \\
(.0021)\end{array}$ & $\begin{array}{l}-.0013 \\
(.0022)\end{array}$ & $\begin{array}{l}-.0008 \\
(.0019)\end{array}$ & $\begin{array}{l}-.0021 \\
(.0017)\end{array}$ & $\begin{array}{l}-.0025 \\
(.0019)\end{array}$ & $\begin{array}{c}-.0032 \\
(.0027)\end{array}$ & $\begin{array}{c}-.0025 \\
(.0020)\end{array}$ \\
\hline cntysub\%puertric & $\begin{array}{c}-.0112^{* * *} \\
(.0033)\end{array}$ & $\begin{array}{c}-.0131^{* * *} \\
(.0027)\end{array}$ & $\begin{array}{c}-.0135^{* *} \\
(.0063)\end{array}$ & $\begin{array}{c}-.0163^{* * * *} \\
(.0054)\end{array}$ & $\begin{array}{l}-.0062 \\
(.0058)\end{array}$ & $\begin{array}{c}-.0070 \\
(.0060)\end{array}$ & $\begin{array}{c}-.0110^{* *} \\
(.0051)\end{array}$ & $\begin{array}{c}-.0135^{* * *} \\
(.0052)\end{array}$ \\
\hline cntysub\%cuba & $\begin{array}{l}.01300 \\
(.0101)\end{array}$ & $\begin{array}{c}.0119 \\
(.0098)\end{array}$ & $\begin{array}{c}.0029 \\
(.0108)\end{array}$ & $\begin{array}{c}.0092 \\
(.0101)\end{array}$ & $\begin{array}{l}-.0141^{*} \\
(.0074)\end{array}$ & $\begin{array}{c}-.0155^{* *} \\
(.0066)\end{array}$ & $\begin{array}{c}-.0164^{* *} \\
(.0074)\end{array}$ & $\begin{array}{c}-.0189^{* *} \\
(.0077)\end{array}$ \\
\hline cntysub\%wasia & $\begin{array}{l}-.0019 \\
(.0022)\end{array}$ & $\begin{array}{l}-.0025 \\
(.0024)\end{array}$ & $\begin{array}{l}-.0008 \\
(.0022)\end{array}$ & $\begin{array}{l}-.0007 \\
(.0021)\end{array}$ & $\begin{array}{l}-.0006 \\
(.0027)\end{array}$ & $\begin{array}{l}-.0010 \\
(.0023)\end{array}$ & $\begin{array}{l}-.0010 \\
(.0020)\end{array}$ & $\begin{array}{l}.0007 \\
(.0018)\end{array}$ \\
\hline cntysub\%easia & $\begin{array}{l}-.0015 \\
(.0012)\end{array}$ & $\begin{array}{l}-.0014 \\
(.0013)\end{array}$ & $\begin{array}{c}.0006 \\
(.0013)\end{array}$ & $\begin{array}{l}-.0011 \\
(.0014)\end{array}$ & $\begin{array}{l}-.0008 \\
(.0012)\end{array}$ & $\begin{array}{l}-.0008 \\
(.0012)\end{array}$ & $\begin{array}{l}-.0004 \\
(.0015)\end{array}$ & $\begin{array}{l}-.0005 \\
(.0011)\end{array}$ \\
\hline cntysub\%europe & $\begin{array}{c}.0036 \\
(.0042)\end{array}$ & $\begin{array}{c}.0030 \\
(.0043)\end{array}$ & $\begin{array}{c}.0040^{*} \\
(.0024)\end{array}$ & $\begin{array}{c}.0014 \\
(.0037)\end{array}$ & $\begin{array}{l}.0090^{* * *} \\
(.0030)\end{array}$ & $\begin{array}{l}.0082^{* *} \\
(.0033)\end{array}$ & $\begin{array}{l}.0074^{* * *} \\
(.0027)\end{array}$ & $\begin{array}{l}.0073^{* * *} \\
(.0026)\end{array}$ \\
\hline
\end{tabular}

Additional Controls:

\begin{tabular}{|c|c|c|c|c|c|c|c|}
\hline wkoutcnty & no & yes & yes & yes & no & yes & yes \\
\hline metro area effects & no & no & yes & yes & no & no & yes \\
\hline D-in-D estimator & no & no & no & yes & no & no & no \\
\hline
\end{tabular}

Note- The dependent variable is equal to 1 if individual is employed; 0 if unemployed. Robust, cluster-adjusted standard errors are in parentheses. All regressions also include education, age, marital status, disability, industry, occupation, and years since migration controls. Columns (3), (4), (7), and (8) include metro area indicators. Columns (4) and (8) also include ethnic group indicators. The coefficients in columns (4) and (8) represent the D-in-D estimates, so they correspond to the interaction of ethnic concentration with the respective ethnic group indicator.

$* p<.10$. ** $p<.05$. *** $p<.01$. 


\section{Appendix}

\section{Table A1}

\section{SELECTED VARIABLE MEANS, MALES}

\begin{tabular}{|c|c|c|c|c|c|c|c|c|}
\hline Variable & $\begin{array}{l}\text { Ethnic } \\
\text { Group: } \\
\text { Mexican }\end{array}$ & $\begin{array}{l}\text { Cent. } \\
\text { Am. }\end{array}$ & $\begin{array}{c}\text { South } \\
\text { Am. }\end{array}$ & $\begin{array}{c}\text { Puerto } \\
\text { Rican } \\
\end{array}$ & Cuban & $\begin{array}{l}\text { West } \\
\text { Asian }\end{array}$ & $\begin{array}{c}\text { East } \\
\text { Asian }\end{array}$ & European \\
\hline grade1-4 & .0641 & .0463 & .0076 & .0139 & .0050 & .0013 & .0043 & .0064 \\
\hline grade5-8 & .2809 & .1962 & .0705 & .0819 & .0526 & .0133 & .0299 & .0356 \\
\hline grade9-11 & .2500 & .2281 & .1355 & .2266 & .1552 & .0640 & .0790 & .0796 \\
\hline hsgraduate & .1763 & .2002 & .2620 & .2843 & .2209 & .1243 & .1386 & .2215 \\
\hline somecoll & .0895 & .1455 & .2156 & .1865 & .2110 & .1184 & .1841 & .1827 \\
\hline assocdeg & .0188 & .0358 & .0617 & .0547 & .0697 & .0547 & .0734 & .0678 \\
\hline bachdeg & .0254 & .0526 & .1349 & .0893 & .1474 & .2940 & .2838 & .2036 \\
\hline mastdeg & .0060 & .0144 & .0503 & .0275 & .0624 & .2130 & .1125 & .1189 \\
\hline profdeg & .0067 & .0089 & .0341 & .0132 & .0485 & .0587 & .0312 & .0332 \\
\hline doctdeg & .0011 & .0024 & .0121 & .0051 & .0148 & .0514 & .0411 & .0441 \\
\hline age & 34.47 & 34.85 & 38.84 & 41.89 & 43.02 & 39.07 & 39.92 & 41.98 \\
\hline onlyeng & .0451 & .0656 & .1935 & .0907 & .1038 & .0878 & .1025 & .3782 \\
\hline goodeng & .4788 & .5685 & .5952 & .7927 & .7006 & .8447 & .7216 & .5342 \\
\hline pooreng & .3053 & .2519 & .1673 & .0986 & .1433 & .0623 & .1515 & .0771 \\
\hline ysm & 15.92 & 15.18 & 16.65 & 26.38 & 25.72 & 14.77 & 17.48 & 22.07 \\
\hline wkoutcnty & .1644 & .2053 & .3938 & .3546 & .3352 & .3483 & .2941 & .3547 \\
\hline
\end{tabular}

Note- Regressions also include age squared, year since migration squared, marital status, disability, industry, occupation, and, in some cases, metro area and ethnic group indicators. 


\section{Appendix (continued)}

Table A2

SELECTED VARIABLE MEANS, FEMALES

\begin{tabular}{|c|c|c|c|c|c|c|c|c|}
\hline Variable & $\begin{array}{l}\text { Ethnic } \\
\text { Group: } \\
\text { Mexican }\end{array}$ & $\begin{array}{l}\text { Cent. } \\
\text { Am. }\end{array}$ & $\begin{array}{c}\text { South } \\
\text { Am. }\end{array}$ & $\begin{array}{l}\text { Puerto } \\
\text { Rican } \\
\end{array}$ & Cuban & $\begin{array}{r}\text { West } \\
\text { Asian } \\
\end{array}$ & $\begin{array}{c}\text { East } \\
\text { Asian } \\
\end{array}$ & European \\
\hline grade1-4 & .0531 & .0370 & .0061 & .0074 & .0053 & .0015 & .0069 & .0053 \\
\hline grade5-8 & .2363 & .1580 & .0501 & .0497 & .0467 & .0121 & .0373 & .0293 \\
\hline grade9-11 & .2089 & .1826 & .1137 & .1505 & .1080 & .0571 & .0727 & .0637 \\
\hline hsgraduate & .2006 & .2167 & .2534 & .2738 & .2115 & .1278 & .1442 & .2296 \\
\hline somecoll & .1363 & .1898 & .2367 & .2296 & .2343 & .1456 & .1687 & .2159 \\
\hline assocdeg & .0359 & .0559 & .0855 & .0882 & .0886 & .0848 & .0857 & .0957 \\
\hline bachdeg & .0413 & .0734 & .1559 & .1242 & .1676 & .3240 & .3383 & .2052 \\
\hline mastdeg & .0100 & .0192 & .0502 & .0499 & .0815 & .1558 & .0834 & .1025 \\
\hline profdeg & .0077 & .0099 & .0275 & .0117 & .0352 & .0592 & .0274 & .0283 \\
\hline doctdeg & .0011 & .0019 & .0081 & .0049 & .0135 & .0259 & .0135 & .0194 \\
\hline age & 36.21 & 37.27 & 39.49 & 41.50 & 43.49 & 38.80 & 39.91 & 42.29 \\
\hline onlyeng & .0509 & .0903 & .2226 & .0782 & .0828 & .0776 & .1141 & .3749 \\
\hline goodeng & .5174 & .5812 & .5855 & .8182 & .7593 & .8361 & .7144 & .5539 \\
\hline pooreng & .2618 & .2242 & .1439 & .0857 & .1142 & .0780 & .1438 & .0625 \\
\hline ysm & 18.42 & 17.51 & 17.58 & 26.54 & 27.96 & 15.04 & 17.70 & 23.60 \\
\hline wkoutcnty & .1028 & .1701 & .3341 & .2852 & .2754 & .2812 & .2484 & .2695 \\
\hline
\end{tabular}

Note- Regressions also include age squared, year since migration squared, marital status, disability, industry, occupation, and, in some cases, metro area and ethnic group indicators. 